\title{
P30. The use of HER2 receptors status as a prognostic index for estrogen receptor positive breast cancer patients
}

\author{
A Tawfeek \\ From 1st Immunotherapy of Cancer Conference (ITOC1) \\ Munich, Germany. 12-14 March 2014
}

\section{Background}

Tamoxifen has been a standard adjuvant hormonal treatment for estrogen receptor ER positive breast cancer, both in pre and postmenopausal women. It has been noticed that some breast cancer patients don't respond to tamoxifen as others. In the presented study, HER2 receptor status has been studied as a probable prognostic index regarding the local recurrence \& disease related mortality \& to differentiate responders from non-responders to tamoxifen treatment.

\section{Methods}

205 patients in the oncology center of Merjan Hospital, Hilla, Iraq who had mastectomy performed and histopathology done studying the ER and HER2 receptor status, all of which ER positive and of early stages (I and II) breast cancer, had been studied prospectively between the fifth of June 2010 and the 19th of June 2011 regarding the local recurrence and mortality during this period. All the patients had been given Tamoxifen tablet 20mg/day.

\section{Results}

56 (27.3\%) were HER2 receptors +ve, and 149 (72.7\%) were HER2 receptor -ve . 19 (33.9\%) and 9(16\%) of the HER2 + ve patients had local recurrence and died due to the disease respectively during the follow up period. $30(20.1 \%)$ and $14(9.4 \%)$ of the HER -ve patients had local recurrence and died of the disease respectively during the follow up period.

\section{Conclusion}

I found a significant difference in the disease local recurrence and mortality of ER+ve HER2 receptor +ve

University of Babylon College Of Medicine, Surgery, Hilla, Iraq as compared with the ER+ve HER2 receptor -ve in favor of the latter and the ER+veHER2 receptor -ve had a much better prognosis.

Published: 12 March 2014

doi:10.1186/2051-1426-2-S2-P21

Cite this article as: Tawfeek: P30. The use of HER2 receptors status as a prognostic index for estrogen receptor positive breast cancer patients. Journal for ImmunoTherapy of Cancer 2014 2(Suppl 2):P21.
Submit your next manuscript to BioMed Central and take full advantage of:

- Convenient online submission

- Thorough peer review

- No space constraints or color figure charges

- Immediate publication on acceptance

- Inclusion in PubMed, CAS, Scopus and Google Scholar

- Research which is freely available for redistribution 